Удк 617.55-089-053.2+615.33

DOI 10.11603/2414-4533.2016.4.7189

(с) А. П. олІйник

Львівський національний медичний університет імені Данила Галицького

\title{
Прогностичні ознаки виникнення післяопераційних гнійно-септичних уск.ладнень у дітей з невідк.ладною абдомінальною патологією
}

\author{
A. P. OLIYNYK
}

Danylo Halytskyi Lviv National Medical University

\author{
PROGNOSTIC SIGNS OF POSTOPERATIVE SEPTIC COMPLICATIONS IN CHILDREN WITH \\ THE URGENT ABDOMINAL PATHOLOGY
}

\begin{abstract}
Методом експертних оцінок з подальшим апріорним ранжируванням визначено прогностичні ознаки виникнення післяопераційних гнійно-септичних ускладнень у дітей з невідкладною абдомінальною патологією. Встановлено, що найбільш суттєве значення мають прогностичні ознаки, пов'язані з операційним втручанням: ступінь “чистоти” операційної рани, тривалість операційного втручання більше 2 год, відтермінованість ургентного операційного втручання. Досить суттєве значення мають прогностичні ознаки, які стосуються даних анамнезу й об'єктивного обстеження.

Using the method of expert assessments, followed by a priori rankings prognostic signs occurrence of postoperative septic complications in children with urgent abdominal pathology were determined. It was found that the most significant prognostic value have symptoms related to surgery, the degree of "purity" of the wound, duration of surgery more than 2 hours, delay urgent surgical intervention. Enough of essential significance there are prognostic features related data history and physical examination.
\end{abstract}

Постановка проблеми і аналіз останніх досліджень та публікацій. Проблема післяопераційних гнійно-септичних ускладнень (ПОГСУ) на сьогодні є актуальною для усіх галузей хірургії. Незважаючи на постійне вдосконалення методики операційних втручань, частота ПОГСУ в дитячій хірургії залишається високою i, за даними Національної системи спостереження за нозокоміальними інфекціями, США займає третє місце у структурі всіх нозокоміальних інфекцій [1]. Розширення діапазону й обсягу операційних втручань на органах черевної порожнини сприяє значному збільшенню частоти післяопераційних ускладнень. Причому найчисленнішу групу займають ускладнення гнійно-септичного характеру. За інших рівних умов гнійно-септичні ускладнення в 3,5 раза частіше зустрічаються в ургентній хірургії, ніж у плановій [2].

У сучасній хірургії намітилася важлива як у практичному, так і в науковому плані тенденція прогнозування та профілактики ПОГСУ. Вона основана на вивченні суті патофізіологічних механізмів, що лежать в основі розвитку ПОГСУ й об'єктивних причинних зв'язків [3]. Головним принципом прогнозування ускладнень в абдомінальній хірургії та їх профілактики є глибоке вивчення доопераційного стану хворого, виявлення чинників ризику, підготовка хворого до операції, оцінка тяжкості майбутнього операційного втру- чання й облік специфічних клінічних проявів післяопераційного періоду. Незважаючи на значну кількість шкал, індексів і методів прогнозування, не до кінця вивчених і нерідко конкуруючих між собою, диференційна діагностика окремих ускладнень залишається тяжким завданням для клініциста і нерідко супроводжується помилками [4].

Аналіз результатів доступних досліджень свідчить про те, що в Україні відсутні достовірні методи прогнозування ризику виникнення ПОГСУ в дітей із невідкладною абдомінальною патологією. Значною мірою це пов'язано з відсутністю достовірних даних про їх частоту (неповна реєстрація), у зв'язку із заходами адміністративного впливу на лікарів, які “винні” в їх виникненні, та відсутністю нормативно затверджених прогностичних ознак виникнення ПОГСУ [5].

Мета роботи: визначення прогностичних ознак виникнення ПОГСУ в дітей з невідкладною абдомінальною патологією для покращення результатів їх лікування.

Матеріали і методи. Визначення прогностичних ознак виникнення ПОГСУ в дітей з невідкладною абдомінальною патологією проводили методом експертних оцінок і подальшого апріорного ранжирування [6]. 3 цією метою, за даними літератури, було сформовано сім груп прогностичних ознак виникнення ПОГСУ (табл. 1). 
Таблиця 1. Прогностичні ознаки виникнення Погсу

\begin{tabular}{|c|c|c|}
\hline $\begin{array}{c}\text { Ранг } \\
\text { ознаки }\end{array}$ & $\begin{array}{c}\text { № } \\
\text { ознаки }\end{array}$ & Найменування прогностичних ознак \\
\hline \multicolumn{3}{|r|}{ 1. Анамнестичні дані } \\
\hline 21 & $\mathrm{X}_{1}$ & Наявність уроджених вад розвитку \\
\hline 5 & $\mathrm{X}_{2}$ & Наявність гострих захворювань на момент операційного втручання \\
\hline 6 & $\mathrm{X}_{3}$ & Наявність супутніх системних захворювань \\
\hline 37 & $\mathrm{X}_{4}$ & Спленектомія в анамнезі \\
\hline \multicolumn{3}{|r|}{ 2. Дані об’єктивного обстеження } \\
\hline 8 & $\mathrm{X}_{5}$ & Ранній дитячий вік - до 3 років \\
\hline 12 & $\mathrm{X}_{6}$ & Наявність дефіциту або надлишку маси тіла \\
\hline 36 & $\mathrm{X}_{7}$ & Підвищення температури тіла вище 38,5 ํㅡ на момент госпіталізації \\
\hline 9 & $\mathrm{X}_{8}$ & Підвищення температури тіла вище $38,5^{0} \mathrm{C}$ протягом трьох днів після операційного втручання \\
\hline 27 & $\mathrm{X}_{9}$ & $\begin{array}{l}\text { Частота дихання, частота серцевих скорочень, які перевищують верхню межу вікової } \\
\text { норми на момент госпіталізації }\end{array}$ \\
\hline 24 & $\mathrm{X}_{10}$ & $\begin{array}{l}\text { Частота дихання, частота серцевих скорочень, які перевищують верхню межу вікової } \\
\text { норми протягом трьох днів після операційного втручання }\end{array}$ \\
\hline \multicolumn{3}{|r|}{ 3. Дані біохімічного аналізу крові } \\
\hline 30 & $\mathrm{X}_{11}$ & Підвищення рівня загального білірубіну \\
\hline 31 & $\mathrm{X}_{12}$ & Підвищення рівня сечовини \\
\hline 32 & $\mathrm{X}_{13}$ & Підвищення рівня креатиніну \\
\hline 33 & $\mathrm{X}_{14}$ & Підвищення рівня лактату \\
\hline 34 & $\mathrm{X}_{15}$ & Підвищення рівня калію в крові \\
\hline 35 & $\mathrm{X}_{16}$ & Підвищення рівня натрію в крові \\
\hline 11 & $\mathrm{X}_{17}$ & Підвищення рівня С-реактивного протеїну \\
\hline 25 & $\mathrm{X}_{18}$ & Підвищення рівня аланінамінотрансферази (ALAT) \\
\hline 26 & $\mathrm{X}_{19}$ & Підвищення рівня аспартатамінотрансферази (ASAT) \\
\hline 15 & $\mathrm{X}_{20}$ & Зниження рівня загального білка \\
\hline 23 & $\mathrm{X}_{21}$ & Зниження гематокриту \\
\hline \multicolumn{3}{|r|}{ 4. Дані коагулограми } \\
\hline 19 & $\mathrm{X}_{22}$ & Вкорочення протромбінового часу \\
\hline 20 & $\mathrm{X}_{23}$ & Підвищення протромбінового індексу \\
\hline 16 & $X_{24}$ & Підвищення рівня фібриногену \\
\hline 28 & $\mathrm{X}_{25}$ & Підвищення ступеня ретракції кров’яного згустка \\
\hline 29 & $\mathrm{X}_{26}$ & Зниження рівня антитромбіну III \\
\hline 18 & $\mathrm{X}_{27}$ & Вкорочення часу зсідання крові за Лі-Вайтом \\
\hline \multicolumn{3}{|r|}{ 5. Дані загального аналізу крові } \\
\hline 4 & $\mathrm{X}_{28}$ & Збільшення швидкості осідання еритроцитів \\
\hline 17 & $\mathrm{X}_{29}$ & Зниження кількості тромбоцитів \\
\hline \multicolumn{3}{|r|}{ 6. Дані загального аналізу сечі } \\
\hline 22 & $\mathrm{X}_{30}$ & Підвищення рівня білка \\
\hline \multicolumn{3}{|r|}{ 7. Прогностичні ознаки, пов’язані з операційним втручанням } \\
\hline 2 & $\mathrm{X}_{31}$ & Тривалість операційного втручання більше 2 год \\
\hline 1 & $\mathrm{X}_{32}$ & Ступінь “чистоти” операційної рани \\
\hline 14 & $\mathrm{X}_{33}$ & Повторні операційні втручання протягом 1 місяця \\
\hline 3 & $X_{34}$ & Відтермінованість ургентного операційного втручання \\
\hline 13 & $\mathrm{X}_{35}$ & Наявність супутніх травматичних пошкоджень \\
\hline 7 & $\mathrm{X}_{36}$ & $\begin{array}{l}\text { Використання інвазивних маніпуляцій (катетеризація сечового міхура, катетеризація централь- } \\
\text { ної вени, ШВЛ, назогастральна інтубація, наявність трахеостоми, наявність дренажів) }\end{array}$ \\
\hline 10 & $\mathrm{X}_{37}$ & Проведення доопераційних, інтраопераційних та післяопераційних гемотрансфузій \\
\hline
\end{tabular}


Експертну оцінку впливу прогностичних ознак на виникнення ПОГСУ в дітей із невідкладною абдомінальною патологією проводили дитячі хірурги м. Львова і Львівської області, науковопедагогічний персонал кафедри дитячої хірургії і кафедри медицини невідкладних станів Львівського національного медичного університету імені Данила Галицького. За стажем практичної роботи анкетовані спеціалісти поділялись таким чином: до 10 років - (1-8), до 20 років - (9-15), до 30 років - (16-23), до 40 років - (24-28), більше 40 років - (29-30).

Дані анкетування обробляли у такому порядку. Для кожної із ознак анкетовані спеціалісти надавали певний ранг. Ознака, яка на думку спеціаліста виявляє найбільший вплив на розвиток ПОГСУ, отримувала найвищий ранг. Для кожної iз прогностичних ознак визначали суму рангів i знаходили відхилення цієї суми від середньої суми рангів.

У зв’язку з деякою неузгодженістю думок спеціалістів визначали коефіцієнт конкордації (W). Значення коефіцієнта конкордації може змінюватись в межах від 0 до 1. Чим менш суттєво воно відрізняється від 0, тим більш узгоджена оцінка експертів. У даному випадку $\mathrm{W}=0,07$, що означає достатньо високу узгодженість оцінок експертів.

3 метою перевірки гіпотези про невипадковість узгодженості оцінок експертів, визначали значимість коефіцієнта конкордації за допомогою критерію Пірсона $\left(\chi^{2}\right)$. Для цього визначали $\chi^{2}$-експер. В результаті обчислень отримали $\chi^{2}$-експер. $=80,09$. Узгодженість оцінок експертів можна вважати не випадковою, якщо $\chi^{2}$-експер. $\geq \chi^{2}-$ табл.

При імовірності $\mathrm{p}=0,95$ і числі ступенів свободи $f$ табличне зачення критерію Пірсона рівне 57,007. Оскільки обчислене значення критерію перевищує табличне, можна зробити висновок, що думки спеціалістів з оцінки впливу прогностичних ознак на виникнення ПОГСУ в дітей з невідкладною абдомінальною патологією узгоджені.

Результати досліджень та їх обговорення. У результаті проведених досліджень встановлено, що до найбільш суттєвих прогностичних ознак виникнення ПОГСУ в дітей з невідкладною абдомінальною патологією, які отримали найвищий ранг оцінки експертів (1-3 місце відповідно) належать ознаки, пов’язані з операційним втручанням: $\mathrm{X}_{32}$ - ступінь “чистоти” операційної рани; $\mathrm{X}_{31}$ тривалість операційного втручання більше 2 год; $\mathrm{X}_{34}$ - відтермінованість ургентного операційного втручання.
Інші прогностичні ознаки, пов’язані з операційним втручанням, також отримали високі ранги оцінки, які перевищують середнє значення суми рангів. До них належать: $\mathrm{X}_{36}$ - використання інвазивних маніпуляцій: катетеризація сечового міхура, катетеризація центральної вени, ШВЛ, назогастральна інтубація, наявність трахеостоми, наявність дренажів (7 місце); $\mathrm{X}_{37}$ - проведення доопераційних, інтраопераційних та післяопераційних гемотрансфузій (10 місце); $\mathrm{X}_{35}$ - наявність супутніх травматичних пошкоджень (13 місце); $\mathrm{X}_{33}$ - повторні операційні втручання впродовж 1 місяця (14 місце).

У даному випадку оцінка експертів збігається із затвердженими МO3 України методичними рекомендаціями “Епідеміологічний нагляд за інфекціями області хірургічного втручання та їх профілактика”, згідно з якими наявність прогностичних ознак, пов’ язаних з операційним втручанням, свідчить про можливість проліферації ендогенних мікроорганізмів, які можуть потрапити в операційну рану, а також колонізації пацієнта внутрішньолікарняними штамами мікроорганізмів.

Значно перевищують середнє значення суми рангів прогностичні ознаки, які стосуються даних анамнезу й об'єктивного обстеження: $X_{2}$ - наявність гострих захворювань на момент операційного втручання (5 місце); $\mathrm{X}_{3}$ - наявність супутніх системних захворювань (6 місце); $\mathrm{X}_{5}$ - ранній дитячий вік - до 3 років (8 місце); $X_{8}$ - підвищення температури тіла вище $38,5{ }^{\circ} \mathrm{C}$ впродовж трьох днів після операційного втручання (9 місце); $\mathrm{X}_{6}$ - наявність дефіциту або надлишку маси тіла (12 місце).

Прогностичні ознаки, які стосуються даних лабораторних досліджень (загального і біохімічного аналізів крові), хоч мінімально, проте перевищують середнє значення суми рангів. До них належать: $\mathrm{X}_{17}$ - підвищення рівня С-реактивного протеїну (11 місце); $X_{20}$ - зниження рівня загального білка (15 місце); $\mathrm{X}_{24}$ - підвищення рівня фібриногену (16 місце); $\mathrm{X}_{29}$ - зниження кількості тромбоцитів (17 місце). Лише одна прогностична ознака, яка належить до цієї групи: $\mathrm{X}_{28}$ - збільшення швидкості осідання еритроцитів - отримала один із найвищих рангів (4 місце).

Суми рангів усіх інших із 37 прогностичних ознак, запропонованих для експертної оцінки, монотонно зменшуються не перевищуючи середнього значення i, на думку експертів, вони не мають суттєвого значення для прогнозування ризику виникнення ПОГСУ в дітей з невідкладною абдомінальною патологією.

Таким чином, прогностичні ознаки виникнення ПОГСУ в дітей із невідкладною абдоміналь- 


\section{З ДОСВІДУ РОБОТИ}

ною патологією відібрані за даними літератури, підтверджені результатами досліджень за допомогою методу експертних оцінок з подальшим апріорним ранжируванням.

Висновки. 1. Встановлено, що до найбільш суттєвих прогностичних ознак виникнення ПОГСУ в дітей 3 невідкладною абдомінальною патологією належать ознаки, пов’язані з операційним втручанням: ступінь “чистоти” операційної рани, тривалість операційного втручання більше 2 год, відтермінованість ургентного операційного втручання.

2. Із прогностичних ознак, які стосуються даних лабораторних досліджень (загального і біохімічного аналізів крові), для прогнозування ризику

\section{СПИСОК ЛІТЕРАТУРИ}

1. Про затвердження методичних рекомендацій “Епідеміологічний нагляд за інфекціями області хірургічного втручання та їх профілактика” / Наказ МОЗ України від 4 квітня 2008 року № 181. [Електронний ресурс]. - Режим доступу : http:// document.ua/metodichni-rekomendaciyi-epidemiologichniinagljad-za-infekc-nor13596.html Дата доступу : 25.07.2016.

2. Руководство по неотложной хирургии органов брюшной полости / под ред. В. С. Савельева. - М. : Изд-во “Триада-Х”, 2005. -640 с.

3. Интенсивная терапия сепсиса / Б. Р. Гельфанд, Д. Н. Проценко, Е. Б. Гельфанд [и др.] // Consilium medicum. - 2003. № 2. - C. 7-12. виникнення ПОГСУ в дітей із невідкладною абдомінальною патологією суттєве значення має лише показник швидкості осідання еритроцитів. Інші показники загального і біохімічного аналізів крові можуть бути використані як прогностичні ознаки, проте суттєвого значення не мають.

3. Прогностичні ознаки, які стосуються даних анамнезу й об'єктивного обстеження - підвищення температури тіла вище $38,5{ }^{\circ} \mathrm{C}$ впродовж трьох днів після операційного втручання, наявність супутніх гострих і системних захворювань, ранній дитячий вік, наявність дефіциту або надлишку маси тіла, мають достатньо суттєве значення для прогнозування ризику виникнення ПОГСУ в дітей з невідкладною абдомінальною патологією.

4. Ходос А. Г. Возможности коррекции работы пищеварительного тракта при перитонитах у детей / Актуальные вопросы хирургической инфекции у детей : материалы Всеросс. симпозиума детских хирургов / А. Г. Ходос, Е. И. Матвеева, Р. А. Кочерова. - Воронеж, 2004. - С. 132.

5. Міщук В. Р. Прогнозування та профілактика гнійно-септичних ускладнень / В. Р. Міщук, О. Є. Борова // Современная педиатрия. - 2009. - № 3. - С. 59-60.

6. Гнатієнко Г. М. Експертні технології прийняття рішень : монографія / Г. М. Гнатієнко, В. Є. Снитюк. - К. : ТОВ “Маклаут”, 2008. - 444 с.

Отримано 26.10.16 